\title{
The Role of Higher Education Leaders to Engage Research
}

\author{
Ainur Rifqi, Aditya Chandra Setiawan, Shelly Andari, Windasari \\ Department of Educational Management \\ Universitas Negeri Surabaya \\ Surabaya, Indonesia \\ ainurrifqi@unesa.ac.id
}

\begin{abstract}
This study seeks to explore the role of the leadership of the college in cultivating research using a qualitative approach. The data collection methods used are interviews, observations, and document studies. Data analysis used is data condensation, data display, and data verification, while the validity test of the data used is the triangulation of source and engineering, and the member check. Results of this study showed that the role of the university leader in the study of research can be done by providing fund support, spreading research information, giving motivation, appropriate policy retrieval related With lecturer research activities, establishing cooperation, facilitating the civitas in research, and through a humanistic approach. The role was implemented so that the lecturers especially the lecturer could familiarize themselves with the research culture.
\end{abstract}

Keywords-role of higher education leader; culture of research; lecturer

\section{INTRODUCTION}

Universities as supporting the development of knowledge to be a milestone for a scientific advancement. Development of this knowledge can be done by implementing follower's ccollege. One of the contents of the followers college is research [1]. Some colleges have dreams of making themselves a research university. However, the dream is only limited to dream, while the implications on the field can be seen the existing colleges have not fulfilled the criteria as research university [2].

The research culture at some colleges in Indonesia is still not visible, even some colleges only look to the eyes of the research task. Therefore, it takes a habituation to the scholarship to conduct research in daily campus life. The habituation is meant by the cultivate.

According Warner and Palfrey man, culture is "the way we do things around here" [3]. Based on this definition means the culture in the organization is the working style employed by employees to perform their duties. This working style that then became the routine of an officer in carrying out the duties given. A habit that is already inherent will be difficult to change and it takes hard work to change. So, does the habit of research. When a lecturer is accustomed to looking at the eyes of research task, it will be difficult to change it.
However, even though the establishment of a research culture in a college is difficult to change, research cultures still need to be. he organizational culture that has been implemented steadily and strongly will result in the satisfaction and motivation of members of the organization and improve the performance of members, especially in research activities [4]. Therefore, in changing the quality of research organization members, it takes good cultural management.

In the study of the research activities needed the role of an educational institution leader. Koontz, O'donnel and Weihrich defines leadership as an art or process affecting subordinates so that they will strive to achieve the organizational objectives that have been compiled with the highest willingness and enthusiasm [5]. In college, leaders have many meanings, namely the Rector or the Chairperson at the college level, the dean at the faculty level, and the Chairman at the majors and course level. All of the leaders in each sector have an important role in the research activities of culture in the faculty. So, the research activity is not only a vision that is only displayed, but to be a reality in college. The university leaders need to implement research values that can influence and lead lecturers in the universities to conduct research in various ways [6], so as to improve the practice of lecturers in Conducting research activities.

In the Oxford Dictionary the role means "actor's part in a play". Based on that meaning the role of an organization means that one's involvement in an activity. In the study of research, role means the leader has a must to engage in familiarizing the scholarship to implement research for the development of knowledge and practice three obligation of lecturers (Tri Dharma of Higher Education). Leaders in college must have a good strategy, so as to lead the direction of cultural change without any resistance from other academic civitas.

Based on this reason, research needs to be done on the role of a university leader in the study of research among lecturers. One of the colleges that can be used as research studies is the Nurul Jadid University. Nurul Jadid University is a higher education institution in a boarding school. Religious culture is very inherent in its academic civitas. But a pity, from the preliminary study conducted by researchers, the university lecturer Nurul Jadid very rarely do research. Lecturers only carry out learning activities in the classroom, while for other 
points of Tri Dharma of Higher Education have not been executed to the fullest.

Since the position reform at the end of 2016, the officials of Nurul Jadid University began to encourage his prayers not only to teach, but to conduct research activities. This is evident with the publication of several new journals to facilitate the lecturers in the work. For example, International Arabic Journals, Islamic education management journals, and several other journals. In addition, the new rector of Nurul Jadid University, began to build networks with companies around such as YTL and IPMOMI (Power plant companies in Probolinggo), to improve research activities and community service.

\section{METHOD}

Research conducted by researchers in this study using qualitative approach. The type of research used is a single case study, which is a study that takes the case in one place. The case studied was about the leadership role in Nurul Jadid University especially in the teaching of research activities among the lecturers.

To obtain the necessary data in this study, researchers gather facts and reality from several sources at the time of the interview. To obtain the informant at the time of the interview, the researcher used the key person of the rector of Nurul Jadid University, KH. Hamid Wahid, M.A. In this study, data sources originated from the rector of Nurul Jadid University, KH. Hamid Wahid, M.A., dean and lecturers at Nurul Jadid University. In addition, the data obtained by researchers is supported with additional data obtained through documentation and relevant images in accordance with the focus of research and field observations conducted.

This research requires the right methods to open the facts that occur in the field naturally, rather than being contrived by the research subject. According to the researchers, the methods needed in this study include interviews, observations, and document analysis.

Data analysis activities conducted by researchers conducted in conjunction with data collection, because between data collection and analysis is an integral activity. The data analysis techniques in this research refer to the opinions of Miles and Huberman which says that there are three steps done in the process of data analysis, namely data condensation, data display, and data verification or withdrawal conclusions [7].

Data validity checks are made to check the reliability and authenticity of the findings in the research. In case of checking the credibility of a data in the study is done in 2 ways: 1) member check, and 2) triangulation. The triangulation used is the source triangulation and the technique triangulation.

\section{RESULTS AND DISCUSSION}

\section{A. Research Culture of Lecturers at Nurul Jadid University}

According to Schein, organizational culture is a model of basic assumptions and beliefs shared by members of the Organization, and is an organizational view of itself and its environment [8]. Research culture is a fundamental belief that belongs to members of the organization regarding the importance of research activities in university. Research culture at Nurul Jadid University can be said to be not good, it is seen that many lecturers only focus on learning and community service activities. Lecturers do not feel the importance of research activities in university.

Research fund that is not owned by Nurul Jadid University is also a constraint that is owned by the college. Funding assistance provided by Nurul Jadid University is not to carry out research activities, but to register on the seminar as a presenter or funding required to be published in research journals of other organizations. Research conducted by lecturers conducted at independent cost. In fact, according to Mohrman, Ma, and Baker; and $\mathrm{Wu}$ the research fund provided by the College supports the creation of research cultures [9] [10]. The granting of funds supports the motivation of lecturers so as to improve their skills in conducting research. As well as Rungfamai [11], the increasing funding aid for research activities will increase the appeal of lecturers in conducting research activities. Funding assistance for lecturers can assist in exploring knowledge and research findings obtained, which is not able to be financed independently.

Nurul Jadid University includes several auxiliary lecturers who have a research culture to support other lecturers. Research Funding for lecturer assistance is given by the original lecturer, namely UIN Sunan Ampel Surabaya. This is in accordance with the opinion's Robbins stating that the organizational culture is a study that investigates the influence of individual behaviour, groups, and structures within the organization for the purpose of applying knowledge through development of organizational effectiveness [12]. The help lecturer recruited by Nurul Jadid University will influence other lecturers' research behaviour, so that the research culture can materialize.

\section{B. Efforts to Cultivate Research Among the Faculty of Nurul Jadid University}

The management of Nurul Jadid University seeks all lecturers accustomed to research activities. Therefore, the head of Nurul Jadid University provides research clinics services under the auspices of the Institute of Publishing, Research, and Community Service (LP3M). The services provided are consulting activities or research guidance to lecturers who will conduct research. According to Sergiovanni efforts made by the rector of Nurul Jadid University is a form of leadership behavior through the technical behavior [13]. Technical behavior means policy-making to build an institution in providing research guidance to lecturers. This role, according to Mulyasa, is also the role of a manager, in regulating the research culture among lecturers [14]. The formation of LP3M according to Johnson in Warner and Palfreyman is a form of effort through the organizational structure [3].

Another effort undertaken by the principal of Nurul Jadid University is to form an online journal in each course. The purpose of the online journal is for research activities to be a habit of lecturers, as well as minimizing plagiarism. Journal support becomes a facility for lecturers to empower lecturers in research activities. According to Johnson in Warner and 
Palfrey man, the effort undertaken by the leadership is an effort to build a lecturer routine so that the research becomes an internalized habit in lecturers [3]. Some journals that are owned by Nurul Jadid University are Kautsar Journal on Islamic Studies published by the Faculty of Islamic Studies, Tematik Journal published by the Department of Teacher Education of Madrasah Ibtidaiyah (PGMI - Teachers of Islamic Elementary School Education), Pedagogic Journal on the study of education published by the Faculty of Islamic Studies (FAI), The Edureligia Journal published by the Department of Islamic Religious Education (PAI), Al-Tanzim Journal published by the Department of Management of Islamic Education (MPI), the IJ-ATL Journal (International Journal of Arabic Teaching \& Learning) published by the Department of Arabic Language Education (PBA), At-Turas Journal on a study published by LP3M, and Afkarina's journal on Islamic Religious Education published by postgraduate. The publication of the journal is an effort to build an existing infrastructure at Universitas Nurul Jadid. Infrastructure development to support research activities in colleges according to Mintrom [15] can affect the appeal of lecturers to conduct research, so that the quantity and quality of research in universities can increase.

Nurul Jadid Univerity also cooperated with other colleges residing in Kopertais IV (coordinator of islamic higher education at East Java) in improving the research culture. Cooperation conducted in the form of management of journals to be able to raise accreditation of college journals. This cooperation activity according to Mohrman, Ma, and Baker is a step that can be pursued in realizing the research university [9]. Mintrom [15] said external support can improve the ability of the university to acquire and develop high quality research input.

In addition, in order for lecturers to be interested in research activities, Nurul Jadid University will hold exhibition activities from the results of lecturer's research. The exhibition is published by poster. Financing of poster making, will be borne by the college. Through the exhibition activities are expected to power the lecturer in conducting research will be higher. According to Johnson in Warner and Palfreyman, exhibition activities conducted by Nurul Jadid University are researches cultural development effort through the direction of symbols [3]. Symbols mean the things that demonstrate the implementation of a culture.

Another effort to improve the culture of research is to provide information to lecturers on research projects held by the Ministry of Religion or the Ministry of Research, Technology, and Higher Education. The information provided is not only the implementation of the research project, but also includes the style of the writing work. This information is not only informational, but also aims to build relationships between university leaders and lecturers. This is what Sergiovanni said it is one of the forms of the rector leadership of human relation [13].

All these efforts are university leadership efforts in improving the research culture. These efforts do not mean without obstructions, especially the personal wishes of the Nurul Jadid University, but the efforts are done by putting forward the needs of the organization and conditioned its leadership behavior. Warrick believes that belief, personal value, and experience affect the leadership style of rector, the Rector needs to conditioned its leadership behavior tailored to the needs of the organization [3].

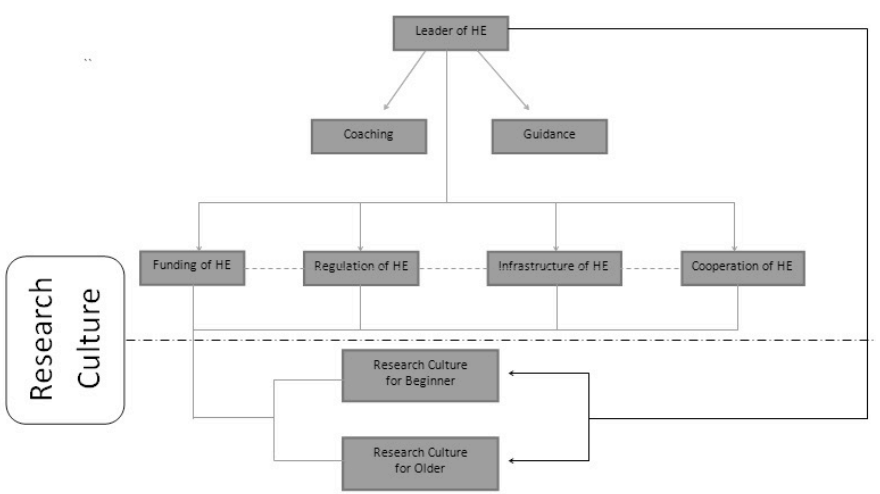

Fig. 1. Role of Higher Education Leader

\section{Performance Lecturer in Research}

The development of college objectives that lead to research activities, encouraging lecturers to actively conduct research activities. Several lecturers, who in the previous period only participated in the learning activities, but since the aim of the Nurul Jadid University emphasizes the research activities, the lecturers little by little carry out research activities. Many lecturers began to consult to functionaries of LP3M about the research activities they will do. What happened at Nurul Jadid University according to the Direktorat Jenderal Pendidikan Tinggi is the fulfillment of direction standards, namely where the objectives of higher education institutions change direction by maximizing research activities [16].

The development of research was also seen from articles received at several international seminars and research projects conducted by Higher Islamic Education. Some lecturer names are often involved and qualify in research activities. This demonstrates the development of lecturers in conducting research. In this realm, colleges are trying to meet results in research activities in which the results of research are desimfied and published in seminar proceedings [16]. Participation in the presentations at international, national, and other seminars is one of the indicators indicating that the research activities in higher education [17].

In addition, the growing journal published in Nurul Jadid University also encouraged the development of research activities of lecturers. Many lecturers want to publish in several new published research journals. It can be seen from the number of articles published in the journal derived from the lecturer of Nurul Jadid University. What happens at the Nurul Jadid University, is also the fulfillment of standard results in the field of research?

\section{CONCLUSION}

The lack of research culture can be caused by many factors such as the absence of research funds provided by the college to support the lecturers conducting research, limited 
information on the research project to address the funding problem, lecturer mindset on the task of the lecturer that is only oriented to the learning process, as well as the habit of lecturers who are only concerned with the orientation of promotion and certification allowance.

The efforts of the university to build a culture of research are through the proper policy collection related to lecturers' research activities, forming research institutions to assist lecturers in solving problems in the field of research, support and motivation given by university in facilitating research activities of lecturers, cooperation activities of university with other organizations to eliminate the existing barrier in college, and a humanistic approach to the leadership of the college's individuals and groups in the organization.

The performance of lecturers in research is the implementation of research activities by lecturers. Some other performance indicators are the implementation of research consultation on institutions provided by the college, the participation of lecturers in publishing the results of research in several journals, and the participation of lecturers in activities scientific workshop such as seminar.

\section{REFERENCES}

[1] H. Etzkowitz, A. Webster, C. Gebhardt, and B. R. C. Terra, "The Future of The University of The Future: Evolution of Invory Tower to Entrepreneurial Paradigm," Res. Policy, vol. 29, no. 2, pp. 313-330, 2000.

[2] R. G. Gonzales and A. G. Ruiz, "Dreaming beyond the fields: Undocumented youth, rural realities and a constellation of disadvantage," Lat. Stud., vol. 12, no. 2, pp. 194-216, 2014.

[3] D. Warner and D. Palfreyman, Higher Education Management: The Key Elements. London: Society for Research into Higher Education, 1996.

[4] R. B. Sumarsono, "Iklim Sekolah, Komitmen Organisasi, Kepuasan Kerja, dan Kinerja Guru," Manaj. Pendidik., vol. 23, no. 1, pp. 532 $539,2012$.

[5] H. Koontz, O’Donnell, and H. Weihrich, Management. Jakarta, 1990.

[6] C. Mitten and D. Ross, "Sustaining a commitment to teaching in a research-intensive university: what we learn from award-winning faculty," Stud. High. Educ., vol. 43, no. 8, pp. 1348-1361, 2018.

[7] B. M. Miles, A. M. Huberman, and J. Saldana, Qualitative Data Analysis A Method Sourcebook, 3rd ed. California: SAGE Publication, Inc, 2014.

[8] E. H. Schein, Organizational Culture and Leadership, 4th ed. San Francisco: Jossey-Bass, 1985.

[9] K. Mohrman, W. Ma, and D. Baker, "The research university in transition: The emerging global model," High. Educ. Policy, vol. 21, no. 1, pp. 5-27, 2008.

[10] W. Wu, "Cultivating Research Universities and Industrial Linkages in China: The Case of Sanghay," Word Dev., vol. 35, pp. 1075-1093, 2007.

[11] K. Rungfamai, "Governance of National Research University in Southeast Asia: the case of Chiang Mai University in Thailand," Stud. High. Educ., vol. 43, no. 7, pp. 1268-1278, 2018.

[12] S. . Robbins, Perilaku Organisasi. Jakarta: PT Indeks Gramedia, 2003.

[13] T. J. Sergiovanni, The Prinsipalship: Dimensions in Instructional Leadership. Boston: Allyn and Bacon, 1991.

[14] E. Mulyasa, Menjadi Kepala Sekolah Profesional. Bandung: Remaja Rosdakarya, 2013.

[15] M. Mintrom, "Managing the research function of the university: Pressures and dilemmas," J. High. Educ. Policy Manag., vol. 30, no. 3, pp. 231-244, 2008
[16] J. P. T. Direktorat, Panduan Pelaksanaan Penelitian dan Pengabdian Kepada Masyarakat di Perguruan Tinggi, IX. Jakarta: Direktorat Penelitian dan Pengabdian kepada Masyarakat, 2013.

[17] N. L. Leech, C. A. Haug, D. Iceman-Sands, and J. Moriarty, "Change in classification level and the effects on research productivity and merit scores for faculty in a school of education," Stud. High. Educ., vol. 40, no. 6, pp. 1030-1045, 2015. 